\title{
Outils, gestes et produits : ressemblances illusoires et contrastes instructifs entre les animaux et l'homme
}

Georges Guille-Escuret

\section{(2) OpenEdition}

Journals

Édition électronique

URL : https://journals.openedition.org/tc/553

DOI : $10.4000 /$ tc. 553

ISSN : 1952-420X

Éditeur

Éditions de l'EHESS

Édition imprimée

Date de publication : 1 novembre 1995

ISSN : 0248-6016

Référence électronique

Georges Guille-Escuret, «Outils, gestes et produits : ressemblances illusoires et contrastes instructifs entre les animaux et l'homme », Techniques \& Culture [En ligne], 23-24 | 1995, mis en ligne le 07 décembre 2005, consulté le 29 septembre 2022. URL : http://journals.openedition.org/tc/553 ; DOI : https://doi.org/10.4000/tc.553

Ce document a été généré automatiquement le 29 septembre 2022.

Tous droits réservés 
Outils, gestes et produits : ressemblances illusoires et contrastes instructifs entre les animaux et l'homme

Georges Guille-Escuret 